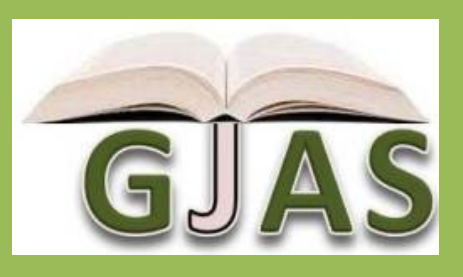

\title{
Lower Illeal Microflora and Growth Performance of Broilers Supplemented with Organic Acid Blend (Aciflex®) During Starter Phase
}

\author{
*Sarzamin Khan, Asad Sultan, Aaqil Muhammad, \\ Naila Imtiaz, Muhammad Mobashar, Hamayun Khan, \\ Mohammad Saleem, Mohammad Inam and Rafiullah
}

Department of Poultry Science, the University of Agriculture, Peshawar-Pakistan.

\section{ARTICLE INFO}

Article No.: 102913935

DOI: 10.15580/GJAS.2013.12.102913935

Submitted: 29/10/2013

Accepted: 22/12/2013

Published: 29/12/2013

${ }^{*}$ Corresponding Author

Sarzamin Khan

E-mail:dr.zaminaup@gmail.com

Keywords:

Organic acid, broilers, growth performance, microflora
Organic acids can be replaced as effective feed additives with antibiotics. Organic acids and their salts have the potential to retard the development of pathogens in the diets and thus maintain the microbial equilibrium in the gastrointestinal tract. In this study, 225 day-old broiler chicks were used for a period of 21 days in order to examine the effect of different levels of organic acids (OA) on performance of broiler. The following parameters: feed intake, water consumption, weight gain, feed conversion ratio (FCR), total Salmonella and E. coli count, weight of visceral organs and length of intestine were studied during starter phase. The experimental chicks were divided into five groups $(n=5,15$ birds/replicate). The chicks in control group OA-0 were offered clean drinking water having no organic acid while those in group OA-1, OA-1.5 and OA-2 were given $1,1.5$ and $2 \mathrm{ml}$ of organic acid blend. Each litter of drinking water contained citric acid $80 \mathrm{~g}$, lactic acid $52 \mathrm{~g}$, phosphorous $92 \mathrm{~g}$, copper sulphate $10 \mathrm{~g}$, respectively. Organic acid $(2 \mathrm{ml} / \mathrm{L})$ supplementation significantly $(p<0.05)$ increased feed intake $(405.37 \mathrm{~g})$, weight gain $(218 \mathrm{~g})$, FCR $(1.42)$, weight of liver $(0.02 \mathrm{~g})$ and gizzard $(0.03 \mathrm{~g})$. Similarly in group OA-2 organic acid supplementation significantly decreased $(p<0.05)$ the total salmonella $\left(1.6 \times 10^{7}\right)$ and $E$. coli $\left(1.7 \times 10^{7} \log C F U / g\right)$ count in intestinal contents. From present findings it was concluded that organic acid supplementation at level of @ $2 \mathrm{ml} / \mathrm{L}$ in drinking water had beneficial effect on broiler performance and also decreased the colonization of intestinal bacterial counts. 


\section{INTRODUCTION}

Poultry production on commercial scale began in Pakistan in 1963. New hybrid varieties were introduced to the poultry. A modern hatchery was established in Karachi by Pakistan International Airlines in shares with the Shaver (Canadian firm) in 1963. A series of layer and broiler farms, feed mills and hatcheries have been established then in the private sector (Mohsin et al., 2008). Poultry, the second biggest industry of Pakistan has developed as an outstanding alternative of beef and mutton. Its value can be recognized from the reality that almost every family in under developed country and every fifth family in developed country is linked directly with poultry sector in one way or the other. Pakistan has produced about 834,000 tons of poultry meat and 13,144 million eggs in 2011-12 (Economic Survey of Pakistan, 2011-12).

Poultry industry is always looking for a new feed supplemented in order to bring improvement in feed effectiveness and chicken health. Organic acids shows potential to be used instead of antibiotics and other feed additives (Hyden, 2000). Organic acids and their salts are able to reduce the growth of microorganism in the feed and thus preserve the microbial balance in the gastrointestinal tract. By modifying intestinal $\mathrm{pH}$, organic acids also enhanced the solubility of the feed ingredient, digestion and absorption of the nutrients (Vogt et al., 1981; Patten and Waldroup, 1988; Skinner et al., 1991).

Ban on the use of antibiotics as growth promoter in animal nutrition in 2006, the nutritionists and researchers attempted other alternative to improve the performance of broiler chicken. Such alternative was the use of organic acids as feed additive in the animal production.

Organic acids and their salts are generally used in many countries as growth promoter while in many countries the use of antibiotic as a growth promoter is banned in livestock and poultry diets. This initiated the scientists to search for alternatives which were helpful for poultry birds and livestock and having nonsignificant impact on consumer health. In alimentary canal there are two types of bacterial populations, one is pathogenic and the other is beneficial commensals. The former inhibits growth which is facilitated by the latter one (Samanta et al., 2010).

Organic acid supplementation has been reported to decrease colonies of pathogens and production of toxic metabolites, improve digestibility of protein and minerals serve as substrates in the metabolism (Kirchgessner and Roth, 1998). Dietary supplementation of organic acids increases the feed conversion ratio and body weight in broiler chicken (Gauthier, 2000) and reduces colonization of pathogens on the intestinal wall, thus prevents damage to the epithelial cells (Langhout, 2000). As beside antibiotics, organic acids have properties of lowering $\mathrm{pH}$ and consequently enhancing protein digestion (Skinner et al., 1991).

Supplementing poultry diets with organic acids has become an important nutritional strategy aimed to improve performance and health status of poultry fed diets. Organic acids, as feed additives have received increasing attention as alternative. They posses tremendous contribution to the effectiveness in the intensive husbandry and provide people with healthy and nutritious poultry products (Patten and Waldroup, 1988). Organic acids may inspire endogenous enzymes, adjusting gut microbial flora and help in maintaining animal's health. The basic principle on the mode of action of organic acids on bacteria is that no dissociated organic acids can penetrate the bacteria cell wall and disrupt the normal physiology of certain types of bacteria (Dhawale, 2005).

\section{MATERIALS AND METHODS}

The research was conducted at the poultry unit of The University of Agriculture, Peshawar. A total of 225- dayold chicks were obtained from commercial market and divided into five groups designated as OA-0, OA-0.5, OA-1, OA-1.5 and OA-2, having 3 replicates of 15 broiler chicks each. Organic acids (i.e. citric acid $80 \mathrm{~g}$, lactic acid $52 \mathrm{~g}$, phosphorus $92 \mathrm{~g}$ and $\mathrm{CuSO}_{4} 10 \mathrm{~g}$ ) were offered to the broiler chicks in group OA-0, OA-0.5, OA$1, \mathrm{OA}-1.5$ and OA-2 at the dose rate of $0,0.5,1,1.5$ and $2 \mathrm{ml} /$ iter respectively for 21 days.

\section{Isolation and identification of Salmonella and E. coli}

Samples were collected from lower part of intestine aseptically and transported at $4^{\circ} \mathrm{C}$ to the bacteriology laboratory of the Animal Health Department. A loop full of broth was streaked on plates of Brilliant Green Agar (Oxoid, Basingstoke, UK) for Salmonella and MacConkey agar (Oxoid, Basingstoke, UK) for E. coli. The plates were incubated at $37^{\circ} \mathrm{C}$ for $24 \mathrm{hrs}$ and suspected colonies of Salmonella from each plate was collected for presumptive identification based on their morphological characteristics and various biochemical tests and the bacteria were counted on bacterial counting machine.

\section{Preparation of culture media}

Commercially available media ready to use were rehydrated in distilled water. The following media were prepared and used during this study.

\section{MacConkey's agar}

MacConkey's agar was used as a selective medium for the isolation and purification of Coliform organism to distinguish lactose fermenting characteristics of bacteria from non- lactose fermenting bacteria.

\section{Preparation}

Commercially prepared dehydrated medium was used at the concentration of $52 \mathrm{~g}$ in every $1000 \mathrm{ml}$ of distilled water. The prepared agar was sterilized in the autoclave for 15 min under $15 \mathrm{lb}$ pressure at $121^{\circ} \mathrm{C}$. The media 
was allowed to cool at $50^{\circ} \mathrm{C}$ and then $15 \mathrm{ml}$ each were distributed into sterilized petri dishes.

\section{Identification of E. coli and Salmonella}

A smear of the culture was prepared on glass slide and fixed for 2 to 3 times over flame. Crystal violet dye (basic stain) was poured on smear for $1 \mathrm{~min}$ and gently washed with water. Then Gram's iodine solution (mordant) was applied on the smear for $1 \mathrm{~min}$ and gently washed with water. For decolorization with ethyle alcohol, it was poured on smear for $15 \mathrm{sec}$ and gently washed with water. Counter stain was done by taking few drops of Safronine for 0.5-1 min and gently washed with water. Blot was air dried and then examined under microscope using 100x oil immersion lens. Pink color and rod shaped organisms were indication of $E$. coli and Salmonella.

\section{Feed Intake and water consumption}

Daily feed intake was used to work out weekly feed intake. Feed intake was calculated by feed offered feed refused and water consumption was calculated by subtracting daily water refused from water offered.

\section{Weight gain and feed conversion ratio (FCR)}

Weekly weight gain was calculated by subtracting initial weight from final weight of each week and weekly FCR was calculated by dividing weekly feed consumed by weekly weight gain.

\section{Weight of carcass and visceral organs and length of intestine}

Two birds were randomly selected from each replicate at the end of experimental period and were slaughtered.
The head, legs, and visceral organs were removed to work out carcass weight. Visceral organs i.e. liver and heart were weighted separately by using an electric digital balance. Intestinal content was removed and length of intestine from duodenum to caecum was measured.

\section{Statistical analysis}

The relative data was analyzed through standard procedure of analysis of variance (ANOVA) using complete randomized design (CRD) as suggested by Steel and Torie (1981). The statistical package SAS (1997) was applied to complete the data analysis.

\section{RESULTS AND DISCUSSION}

This research was performed to evaluate the effect of organic acids on the performance of broiler chicks. The following results were obtained.

\section{Water Intake and feed consumption}

Mean data showed no $(P>0.05)$ effect on water intake from the first day of the experiment till end (Table 1). However, numerical variation was observed among the groups treated with organic acid to that of control. Higher water intake was observed in group that was fed with organic acid at rate of $2 \mathrm{ml} /$ lit of drinking water and followed by the group at the rate of $1.5 \mathrm{ml} /$ lit of drinking water. It seems that organic acid has improved water quality by minimizing microbial load that normally disturbs drinking quality and smell. Due to better water taste the birds may have consumed more water than non- treated water.

Table 1: Mean water intake $(\mathrm{ml})$ in broiler chicks for the three weeks treated with organic acid

\begin{tabular}{lllll}
\hline \multirow{2}{*}{ Groups } & Week 1 & Meek $\mathbf{2}$ & Week 3 & Over all \\
\cline { 2 - 5 } Control & $399.99 \pm 8.81$ & $766.66 \pm 43.33$ & $1269.11 \pm 61.69$ & $811.62 \pm 37.94$ \\
OA-0.5 & $406.00 \pm 19.25$ & $869.33 \pm 4.44$ & $1381.55 \pm 41.48$ & $885.62 \pm 21.72$ \\
OA-1 & $373.33 \pm 21.16$ & $813.33 \pm 33.38$ & $1384.45 \pm 41.82$ & $857.03 \pm 32.12$ \\
OA-1. 5 & $418.08 \pm 11.22$ & $878.89 \pm 9.49$ & $1435.56 \pm 65.47$ & $910.84 \pm 28.72$ \\
OA-2 & $411.11 \pm 8.01$ & $876.00 \pm 28.00$ & $1471.11 \pm 53.51$ & $919.40 \pm 29.94$ \\
\hline P-Value & 0.3145 & 0.0649 & 0.1669 & \\
\hline Means with different superscript in column are significantly different at $\alpha=0.05$ &
\end{tabular}


Data showed that feed consumed by the birds throughout the experimental period was significantly different $(P<0.05)$ in all treatments (Table 2). The organic acid at high dose rate in the present study showed significantly $(P<0.05)$ higher feed consumption. Highest feed consumption (405.37 g) was recorded for treatment OA-2, while lowest feed consumption (265.29 g) was noted in control group. Similarly, highest weekly feed consumption $\left(585.08 \mathrm{~g}\right.$ ) was achieved on $3^{\text {rd }}$ week, while lowest feed consumption (139.94 g) was observed on $1^{\text {st }}$ week. Results of this study are justified with
Mohamed and Bahnas (2009), who reported significant effect $(P<0.05)$ on feed intake by using malic acid supplementation as a growth promoter. Organic acids increase gastric proteolysis and enhance digestibility of protein and amino acids, decrease the $\mathrm{pH}$ of the gut which improves the bird performance (Samanta et al., 2010). However, present results are in contrast to the findings of Sacakli et al. (2006) who reported nosignificant $(P<0.05)$ effect on feed intake while using organic acid which might be due to different acids used in the studies.

Table 2: Mean feed consumed (gm) in broiler chicks treated with organic acid.

\begin{tabular}{lcccc}
\hline \multirow{2}{*}{ Group } & \multicolumn{3}{c}{ Mean \pm SE } & Meek \\
\cline { 2 - 4 } & Week 1 & Week 2 & Week 3 & $265.29^{\mathrm{e}} \pm 6.87$ \\
\hline Control & 123.771 .89 & $172.2^{\mathrm{c}} \pm 10.29$ & $499.1^{\mathrm{cd}} \pm 8.44$ & $292.59^{\mathrm{d}} \pm 19.183$ \\
OA-0.5 & $123.37^{\mathrm{c}} \pm 4.71$ & $267.89^{\mathrm{b}} \pm 18.40$ & $486.42^{\mathrm{d}} \pm 34.44$ & \\
OA-1 & $141.31^{\mathrm{b}} \pm 2.63$ & $285.93^{\mathrm{ba}} \pm 11.58$ & $554.71^{\mathrm{c}} \pm 18.68$ & $327.31^{\mathrm{c}} \pm 10.96$ \\
OA-1.5 & $150.17^{\mathrm{b}} \pm 2.56$ & $273.71^{\mathrm{ba}} \pm 10.44$ & $638.53^{\mathrm{b}} \pm 38.49$ & $354.13^{\mathrm{b}} \pm 17.16$ \\
OA-2 & $161.08^{\mathrm{a}} \pm 3.41$ & $309.17^{\mathrm{a}} \pm 8.79$ & $745.86^{\mathrm{a}} \pm 11.89$ & $405.37^{\mathrm{a}} \pm 8.03$ \\
\hline P-Value & 0.0001 & 0.0001 & 0.0001 & 0.001 \\
\hline
\end{tabular}

Means with different superscript in column are significantly different at $\alpha=0.05$

\section{Weight gain}

The organic acid at high dose rate showed significantly $(P<0.05)$ higher weight gain as compared to the other treatments and control group (Table 3). Pooled data showed that highest weight gain $(218.03 \mathrm{~g})$ was recorded for treatment OA-2, while lowest weight gain $(182.67 \mathrm{~g})$ by the chicks was noted in control group. Similarly, in the case of week highest weight gain $(357.28 \mathrm{~g})$ by the chicks was achieved on $3^{\text {rd }}$ week, while lowest weight gain $(98.08 \mathrm{~g})$ was noted on $1^{\text {st }}$ week.

Table 3: Mean weight gain (g) of broiler chicks treated with organic acid.

\begin{tabular}{|c|c|c|c|c|}
\hline \multirow{2}{*}{ Group } & \multicolumn{3}{|c|}{ MeanıSE } & \multirow[b]{2}{*}{ Overall } \\
\hline & Week 1 & Week 2 & Week 3 & \\
\hline Control & $89.13^{\mathrm{C}} \pm 2.07$ & $130.13 \pm 4.69$ & $328.77^{d} \pm 7.20$ & $182.67^{e} \pm 4.65$ \\
\hline OA-0.5 & $87.11^{b c} \pm 4.41$ & $159.44 \pm 5.02$ & $350.55^{\complement} \pm 2.89$ & $199.03^{\mathrm{d}} \pm 4.10$ \\
\hline OA-1 & $99.86^{\mathrm{ba}} \pm 8.98$ & $157.13 \pm 13.05$ & $359.77^{\mathrm{cb}} \pm 0.77$ & $205.58^{\mathrm{c}} \pm 7.6$ \\
\hline OA-1.5 & $104.28^{\mathrm{ba}} \pm 3.24$ & $146.31 \pm 18.16$ & $367.66^{a} \pm 3.02$ & $206.08^{b} \pm 8.14$ \\
\hline OA-2 & $110.06^{a} \pm 4.11$ & $164.38 \pm 9.56$ & $379.66^{a} \pm 1.67$ & $218.03^{a} \pm 5.11$ \\
\hline P-Value & 0.0440 & 0.2865 & 0.0001 & 0.001 \\
\hline
\end{tabular}

Means with different superscript in column are significantly different at $\alpha=0.05$

The present results are in line with the findings of Dibner and Buttin (2002), who showed that organic acids improve protein and energy digestibility by reducing microbial competition with the host for nutrients and endogenous nitrogen losses, by lowering the incidence of subclinical infections and secretion of immune mediators, and by reducing production of ammonia and other growth-depressing microbial metabolites. Adil et al. (2011) also found the same results and mentioned that the antimicrobial and $\mathrm{pH}$ reducing properties of organic acids have resulted in inhibition of intestinal bacteria leading to the reduced bacterial competition with the host for available nutrients and decreasing the level of toxic bacterial products resulting in improvement of protein and energy digestibility, thereby increasing the weight gain and performance of broiler chicken. Our 
results match with the following authors (Patten and Waldroup, 1988; Skinner et al., 1991; Mujdat et al., 1999; Adil et al., 2010) who stated that weight gain was significantly affected on week 3 by organic acid.

\section{Feed conversion ratio (FCR)}

The feed conversion ratio by the birds in week 2 and week 3 are significantly different $(P<0.05)$ while nonsignificant in week $1(p>0.05)$ (Table 4). The organic acid at high dose rate in the present study showed significantly $(P<0.05)$ highest feed conversion ratio (1.38) on week $1^{\text {st }}$ for treatment O A - 2, while lowest feed conversion ratio (1.46) for control. Similarly, on $2^{\text {nd }}$ week highest feed conversion ratio (1.32) was achieved for treatment OA-2, while lowest feed conversion ratio (1.88) was noted for control. On week $3^{\text {rd }}$ highest feed conversion ratio (1.38) was noted for treatment $\mathrm{OA}-1.5$, while lowest feed conversion ratio (1.96) was noted for control. The feed conversion ratio results in present study are supported by Samanta et al. (2010) who stated that organic acids reduce $E$. coli and other harmful bacteria which increase poultry growth. It also produces acidic condition that makes the nutrients more available for better performance (Boling et al., 2001). Similarly, our result are also in line with Hassan et al. (2010) who stated that organic acids significantly $(p<0.001)$ improved feed conversion ratio. These results also agreed with the findings of Isabel and Santos (2009); Parker (2011), who investigated that organic acid has significantly affected the FCR. However, present results are contrasted by Sacakli et al. (2006) who reported no significant effect $(P>0.05)$ on FCR by phytase and organic acid.

Table 4: Mean feed conversion ratio (FCR) of broiler chicks fed with organic acid.

\begin{tabular}{lcccc}
\hline \multirow{2}{*}{ Group } & \multicolumn{3}{c}{ Mean \pm SE } & Over all \\
\cline { 2 - 4 } & Week 1 & Week 2 & Week 3 & $1.76^{\mathrm{a}} \pm 0.04$ \\
Control & $1.46 \pm 0.02$ & $1.88^{\mathrm{a}} \pm 0.09$ & $1.96^{\mathrm{a}} \pm 0.02$ & $1.68^{\mathrm{b}} \pm 0.05$ \\
OA-0.5 & $1.44 \pm 0.01$ & $1.87 \mathrm{~b}^{\mathrm{a}} \pm 0.06$ & $1.73^{\mathrm{b}} \pm 0.08$ & $1.58^{\mathrm{b}} \pm 0.14$ \\
OA-1 & $1.41 \pm 0.13$ & $1.81^{\mathrm{b}} \pm 0.04$ & $1.54^{\mathrm{a}} \pm 0.09$ & $1.49^{\mathrm{d}} \pm 0.03$ \\
OA-1. 5 & $1.41 \pm 0.04$ & $1.68^{\mathrm{b}} \pm 0.04$ & $1.38^{\mathrm{d}} \pm 0.03$ & $1.40^{\mathrm{c}} \pm 0.08$ \\
OA-2 & $1.38 \pm 0.02$ & $1.32^{\mathrm{c}} \pm 0.08$ & $1.52^{\mathrm{a}} \pm 0.15$ & 0.001 \\
\hline P-Value & 0.9309 & 0.0302 & 0.0006 & \\
\hline
\end{tabular}

Means with different superscript in column are significantly different at $\alpha=0.05$

\section{Total salmonella and E. coli counts}

Total salmonella count (TSC) was significantly decreased on day $21(\mathrm{P}<0.05)$ but no effect on day 0 $(P>0.05$ (Table 5). The organic acid at high dose rate showed significantly $(P<0.05)$ lower TSC as compared to the other treatments including control groups. Highest TSC (2.9) was recorded in control treatment, while lowest TSC (2.2) were noted for OA-1.5 and OA-2 respectively. Similarly, TSC was higher (2.8) at beginning of experiment while lower (1.6) at the end.
The organic acids eliminate the coliforms from the gastrointestinal tract by reducing the $\mathrm{pH}$, which is unsuitable for the multiplication of the acid-intolerant species such as E. coli and Salmonella (Panda et al., 2009). Our results are in line with Hassen (2011); Park (2011), who stated that total salmonella and E. coli counts were significantly affected by organic acid. Organic acids reduce $E$. coli and other harmful bacteria which may have enhanced poultry growth (Samanta et al., 2010).

Table 5: Mean of Total Salmonella count (TSC) in broiler chicks treated with organic acid (Log CFU/g)

\begin{tabular}{|c|c|c|c|}
\hline \multirow{2}{*}{ Group } & \multicolumn{2}{|c|}{ Mean \pm SE } & \multirow{2}{*}{ Over all } \\
\hline & TSC 0 & TSC 21 & \\
\hline Control & $2.9 \pm 0.33$ & $2.4^{\mathrm{a}} \pm 0.33$ & $2.6^{\mathrm{a}} \pm 0.33$ \\
\hline OA-0.5 & $2.9 \pm 0.57$ & $1.9^{a} \pm 0.88$ & $2.4^{b} \pm 0.72$ \\
\hline OA-1 & $2.8 \pm 1.15$ & $1.9^{b} \pm 0.57$ & $2.3^{c} \pm 0.86$ \\
\hline OA-1.5 & $2.7 \pm 1.20$ & $1.7^{c} \pm 0.57$ & $2.2^{\mathrm{cd}} \pm 0.88$ \\
\hline OA-2 & $2.8 \pm 0.33$ & $1.6^{c} \pm 0.57$ & $2.2^{\mathrm{cd}} \pm 0.45$ \\
\hline P-Value & 0.5995 & 0.0001 & 0.001 \\
\hline
\end{tabular}

Total E. coli count (TEC) was significantly decreased on day $21(P<0.05)$ (Table 6). The organic acid at high dose rate showed significantly $(\mathrm{P}<0.05)$ lower $T E C$ as compared to the other treatments and control groups. While highest TEC (2.6) was recorded in control treatment. 
Table 6. Mean of Total E. coli Count (TEC) in broiler chicks treated with organic acid (Log CFU/g)

\begin{tabular}{lccc}
\hline \multirow{2}{*}{ Group } & \multicolumn{2}{c}{ Mean \pm SE } & Over all \\
\cline { 2 - 3 } & TEC 0 & TEC 21 & $2.6^{\mathrm{a}} \pm 0.72$ \\
Control & $2.9 \pm 0.57$ & $2.4^{\mathrm{a}} \pm 0.88$ & $2.5^{\mathrm{ab}} \pm 0.77$ \\
OA-0.5 & $2.7 \pm 0.88$ & $2.3^{\mathrm{a}} \pm 0.66$ & $2.5^{\mathrm{ab} \pm 0.61}$ \\
OA-1 & $2.9 \pm 0.66$ & $2.1^{\mathrm{b}} \pm 0.57$ & $2.3^{\mathrm{c}} \pm 0.77$ \\
OA-1.5 & $2.8 \pm 0.66$ & $1.8^{\mathrm{c}} \pm 0.88$ & $2.3^{\mathrm{c}} \pm 0.16$ \\
OA-2 & $2.9 \pm 0.66$ & $1.7^{\mathrm{d}} \pm 0.57$ & \\
\hline & & & 0.001 \\
\hline
\end{tabular}

Means with different superscript in column are significantly different at $\alpha=0.05$

Gizzard, Liver and carcass weights and Intestine length

The gizzard and liver weights of the birds were significantly different $(P<0.05)$ while intestine length and carcass weight were non-significant on day $21(p>0.05)$ (Table 7). The organic acid at high dose rate in the present study showed significantly $(\mathrm{P}<0.05)$ larger gizzard $(0.03 \mathrm{~g})$ and liver weight $(0.021 \mathrm{~g})$ as compared to the other treatment and control group, while lowest gizzard weight $(0.024 \mathrm{~g})$ and lowest liver weight $(0.01 \mathrm{~g})$ for control was achieved for control. Highest intestine length (4.86 Inc) was recorded in OA-0.5 treatment, while lowest intestine length (4.50 Inc) was noted in control. Highest carcass weight $(458.66 \mathrm{~g})$ was found in OA-2, while lowest carcass weight (368.66 g) was noted in control treatment.

Table 7: Mean of gizzard ( $\mathrm{g}$ ), liver ( $\mathrm{g}$ ) and carcass wt ( $\mathrm{g}$ ) and intestine length (inch) broiler chicks treated with organic acid.

\begin{tabular}{lcccc}
\hline Group & \multicolumn{2}{c}{ Mean \pm SE } \\
& Gizzrad wt (g) & Liver wt(g) & $\begin{array}{c}\text { Intestine length } \\
\text { (inch) }\end{array}$ & Carcass wt (g) \\
\hline Control & $0.024^{\mathrm{a}} \pm 0.001$ & $0.01^{\mathrm{b}} \pm 0.00$ & $4.50 \pm 0.2886751$ & $368.66 \pm 59.62$ \\
OA-0.5 & $0.03^{\mathrm{b}} \pm 0.002$ & $0.01^{\mathrm{a}} \pm 0.001$ & $4.86 \pm 0.18$ & $404.00 \pm 17.15$ \\
OA-1 & $0.03^{\mathrm{a}} \pm 0.002$ & $0.021^{\mathrm{a}} \pm 0.001$ & $4.40 \pm 0.23$ & $420.00 \pm 2.51$ \\
OA-1.5 & $0.02^{\mathrm{ab}} \pm 0.001$ & $0.02^{\mathrm{a}} \pm 0.00$ & $4.70 \pm 0.35$ & $417.00 \pm 10.21$ \\
OA-2 & $0.03^{\mathrm{ab}} \pm 0.001$ & $0.02^{\mathrm{a}} \pm 0.00$ & $4.83 \pm 0.24$ & $458.66 \pm 19.36$ \\
\hline P-Value & 0.0031 & 0.0499 & 0.6746 & 0.3657 \\
\hline \multicolumn{4}{l}{ Means with different superscript in column are significantly different at $\alpha=0.05$} &
\end{tabular}

Results of the present study are justified by Islam et al. (2008) who reported positive effect $(\mathrm{P}<0.05)$ on liver weight by citric acid and acetic acid in broilers. Our results do not match with Adil et al. (2011) who stated that intestine length was significantly affected by organic acid. Similarly, the findings of Mujadat et al. (1999) match with our results, who stated that carcass was non-significantly affected by organic acid. Our results are in contrast with the observations recorded by Denli et al. (2003) who reported significant increase in intestinal length by supplementation of different organic acids in broiler chicken. This could be increase in the goblet cell size and villus height that was improved due to organic acid supplementation (Çelik and Mutluay, 2007). This indicates improved intestinal length. That led to enhanced growth performance of broiler birds. The difference of the result may be due to the difference of acid used by the previous authors.

\section{CONCLUSIONS}

It was concluded from present results that organic acid has significantly increased feed intake, body weight gain, FCR, gizzard and liver weight in broiler chicks. Organic acid at the level of OA-2 (2ml/1L drinking water) improved the gut efficacy and significantly decreased the total Salmonella and E .coli Counts as compared to control group.

\section{LITERATURE CITED}

Adil S., T. Banday, G.A. Bhat, M. Salahuddin, M. Raquib and S. Shanaz. 2011. Response of broiler chicken to dietary supplementation of organic acids. J. of cen. Eup. Agri. 12(3): 498-508.

Adil, S., T. Banday, G.A. Bhat, M.S. Mir and M. Rehman. 2010. Effect of dietary supplementation of organic acids on performance, intestinal histomorphology, and serum biochemistry of broiler chicken. Vet. Med. Int. 7: 4061479485.

Boling, S.D., J.L. Snow, C. M. Parsons and D.H. Baker. 2001. The effect of citric acid on calcium and phosphorus requirements of chicks fed corn soybean meal diets. Poult. Sci. 80: 783-788.

Çelik K and Mutluay M (2007). Effects of probiotic and organic acid on performance and organ weights in broiler chicks. Archiva Zootechnica. 10: 51-56.

Denli M., F. Okan and K. Celik. 2003. Effect of dietary probiotic, organic acid and antibiotic supplementation to diets on broiler performance and carcass yield. Pak. J. of Nutr. 2: 89-91.

Dhawale, A. 2005. Better egg shell quality with a gut acidifier. Poult. Int. 44: 18-21. 
Dibner, J.Jand P. Buttin. 2002. Use of organic acids as a model to study the impact of gut microflora on nutrition and metabolism. Journal of Applied Poultry Research. 11(4): 453-463.

Economic Survey of Pakistan. 2011. Ministry of Food, Agriculture and Livestock,. government of Pak. Islamabad, Livestock and Poultry Pp: 25-28

Gauthier R (2000). Intestinal health, the key to productivity (The case of organic acids) XXVII Convencion ANECAWPDSA. Puerto Vallarta, Jal. Mexico.56: 4045-4050.

Hassan, H.M.A., M.A. Mohamed, A.W. Youssef and E.R. Hassan. 2010. Effect of using organic acids to substitute antibiotic growth promoters on performance and intestinal microflora of broilers. Asian-Aust. J. Anim. Sci. (23)10: $1348-1353$.

Hyden, M. 2000. Protected acid additives. Feed Int., 7 : 14-16. Bang. J. Anim. Sci. 2008, 37(2).

Isabel, B. and Y. Santos. 2009. Effects of dietary organic acids and essential oils on growth performance and carcass characteristics of broiler chickens. J. Appl. Poult. Res. 18: 472-476.

Islam, M.Z. Z.H. Khandaker., S.D. Chowdhury and K.M.S. Islam. 2008. Effect of citric acid and acetic acid on the performance of broilers.J. Bangla. Agri. Univ. 6(2): 315320.

Kirchgessner, M. and F.X. Roth. 1998. Ergotrope effekte durch organische sauren in der fekelaufzucht und schweinemast. Ubersichten zur Tiererenährung. 16: 93108.

Langhout, P. 2000. New additives for broiler chickens. Feed Mix. 24-27.

Mohamed and S. Bahnas. 2009. Effect of using malic acid on performance of Japanese quail fed optimal and suboptimal energy and protein levels. Egypt. Poult. Sci. 29 (I): 263-286.

Mohsin, A.Q., R. Riaz, S. Asad and A. Mushtaq. 2008. Profitability analysis of broiler production in Rawalpindi district. Pak. J. Agri. Sci., Vol. 45(4):514-519.
Mujadat A. L.P, Kocabagli N and Kahraman R (1999). Effects of dietary supplementation with organic acids and zinc bacitracin on ileal microflora, $\mathrm{pH}$ and performance in broilers. Tr. J. of Veterinary and Animal Sciences. 23: 451-455.

Park, B.S. 2011. Effects of pitamin on growth performance, carcass characteristics and cecal microflora of broiler chicken. J. Environ. Biol. 32(5):5 85-90.

Panda, A.K., S V.R. Rao, M.V.L.N. Raju and G. S. Sunder. 2009. Effect of butyric acid on performance, gastrointestinal tract health and carcass characteristics in broiler chickens. Asian-Aust. J. Anim. Sci. 22(7): 10261031.

Patten, J.D and P.W. Waldroup. 1988. Use of organic acids in broiler diets. Poult. Sci. 67(8):1178-1182.

SAS, SAS User guide, statistics. SAS Institute. Inc. Cary, NC (1997).

Sacakli P., A. Sehu, A. Ergun, B. Genc and Z. Selcuk. 2006. The effect of phytase and organic acid on growth performance, carcass yield and tibia ash in quails fed diets with low levels of non-phytate phosphorus. AsianAust. J. Anim. Sci. 19:198-202.

Samanta, S., S. Haldar and T.K. Ghosh. 2010. Comparative efficacy of an organic acid blend and bacitracin methylene disalicylate as growth promoters in broiler chickens: effects on performance, gut histology, and small intestinal milieu. Vet. Med. Int. 10(4) 061645150.

Skinner, J.T., A.L. Izat and P.W. Waldroup. 1991. Fumaric acid enhances performance of broiler chickens. Poult. Sci. 70: 1444-1447.

Steel, R.G. D and J.H. Torrie. 1981. Principles and procedures of statistics. A biometrical approach. $2^{\text {nd }}$ Ed. McGraw-Hill, Singapore.

Vogt, H., Mathes, S. and Harnisch, S. 1981. The effects of organic acids in the rations on the performance of broiler and laying hens. Arch. Geft., $45: 221-232$.

Cite this Article: Khan S, Sultan A, Muhammad A, Imtiaz N, Mobashar M, Khan H, Saleem M, Inam M and Rafiullah (2013). Lower Illeal Microflora and Growth Performance of Broilers Supplemented with Organic Acid Blend (Aciflex®) During Starter Phase. Greener Journal of Agricultural Sciences, 3(12): 794-800, http://doi.org/10.15580/GJAS.2013.12.102913935. 